\title{
ANALISIS INVESTASI SAHAM PADA PERUSAHAAN PERAIH PENGHARGAAN PROPERTY AWARD 2018 YANG LISTED DI BEI DENGAN MENGGUNAKAN CAPITAL ASSET PRICING MODEL
}

\author{
Hadi Ahmad Sukardi ${ }^{1}$ \\ Universitas Sangga Buana YPKP Bandung \\ hadi.ahmads@usbypkp.ac.id
}

\begin{abstract}
Abstrak - Pertumbuhan sektor properti di Indonesia semakin berkembang pesat, dimana hal ini bisa dilihat dengan banyaknya perusahaan yang berdiri dan menjalankan operasionalnya dalam bentuk proyek-proyek. Hal ini peneliti lakukan untuk membantu menganalisa perusahaan-perusahaan induk yang anak-anak perusahaannya mendapatkan penghargaan dari warta ekonomi berupa beberapa kategori dalam memperoleh property award pada tahun 2018 dan bertujuan membandingkan perusahaan-perusahaan tersebut dan dikatakan layak berinvestasi di perusahaan-perusahaan tersebut. Dalam penelitian ini, peneliti hanya memperoleh sebanyak 23 saham perusahaan yang terpilih sebagai sampel penelitian dengan menggunakan purposive sampling. Hasil yang didapat oleh peneliti dalam analisis ini terdapat 5 saham efisien dan 18 saham tidak efisien berdasarkan perhitungan CAPM. Saham efisien adalah saham undervalued dengan nilai $\mathrm{R}_{\mathrm{i}}>$ nilai $\mathrm{E}\left(\mathrm{R}_{\mathrm{i}}\right)$. Saham-saham efisien tersebut yakni : PPRO, EMDE, JSPT, DMAS dan PWON. Sedangkan saham yang tidak efisien adalah saham yang memiliki nilai $\mathrm{R}_{\mathrm{i}}<$ nilai $\mathrm{E}\left(\mathrm{R}_{\mathrm{i}}\right)$ dan dikatakan sebagai saham overvalued. Saham-saham tidak efisien tersebut yakni : APLN, DILD, ELTY, KIJA, SMDM, LPKR, BSDE, SMRA, CTRA, MDLN, COWL, ASRI, MTLA, GPRA, RODA, GWSA, LPCK dan BEST. Dilain sisi peneliti memperoleh penjelasan bahwa tingkat risiko tidak selalu berhubungan linier dengan tingkat pengembalian, dimana hal ini terlihat ketika peneliti menganalisa hasil risiko sistematis $\beta$ (beta) yang hubungannya terbalik dengan ekspektasi pengembalian $\mathrm{E}\left(\mathrm{R}_{\mathrm{i}}\right)$, dengan adanya perubahan posisi perusahaan yang memiliki risiko paling tinggi ternyata ekspektasi pengembaliannya rendah dan perusahaan yang memiliki risiko paling rendah justru ternyata ekspektasi pengembaliannya menjadi tinggi, hal ini terjadi pada perusahaan BEST dan ELTY. Hasil pengambilan hipotesis yaitu tidak semuanya perusahaan yang dapat peraih property award yang bisa dibeli sahamnya tetapi hanya sebagian saja.
\end{abstract}

Kata Kunci: Model Harga Aset Modal, Pengembalian Individual, Pengembalian Pasar, Resiko dan Pengembalian yang Diharapkan 
Abstract - The growth of the property sector in Indonesia is growing rapidly, where this can be seen with the number of companies that stand up and run operations in the form of projects. This is done by researchers to help analyze the parent companies whose subsidiaries received awards from the journalists in the form of several categories in obtaining property awards in 2018 and aimed at comparing these companies and said to be worth investing in those companies. In this study, researchers only obtained as many as 23 company shares that were selected as research samples by using purposive sampling. The results obtained by researchers in this analysis there are 5 efficient shares and 18 inefficient stocks based on the CAPM calculation. An efficient stock is an undervalued stock with a value of $R$ i> value $E$ $\left(R_{-} i\right)$. These efficient stocks are: PPRO, EMDE, JSPT, DMAS and PWON. While inefficient stocks are stocks that have a value of $R_{-} i<$ value of $E\left(R \_i\right)$ and are said to be overvalued shares. The inefficient stocks are: APLN, DILD, ELTY, KIJA, SMDM, LPKR, BSDE, SMRA, CTRA, MDLN, COWL, ASRI, MTLA, GPRA, WHEEL, GWSA, $\angle P C K$ and BEST. On the other hand the researcher gets the explanation that the level of risk is not always linearly related to the rate of return, where this is seen when the researcher analyzes the results of systematic risk $\beta$ (beta) whose relationship is inversely related to the expected return of $E\left(R \_i\right)$, with a change in the position of the company that has the most risk high turns out to have low return expectations and the company with the lowest risk actually turns out to have high return expectations, this happens to BEST and ELTY companies. The results of making a hypothesis that not all companies that can win property awards can be bought but only partial shares.

Keywords: Capital Asset Pricing Model, Return Individual, Return Market, Risk and Expected Return

\section{PENDAHULUAN}

Kemungkinan besar laju pertumbuhan sektor properti di Indonesia semakin berkembang dengan berbagai macam produk properti yang dipasarkan, baik dilakukan oleh para pengembang profesional maupun baru terjun.

Semakin banyak pebisnis yang terjun dalam sektor industri ini, maka semakin terpacunya suatu ide pengembangan produk untuk lebih baik lagi dalam pemasarannya. Pada hari Kamis, 05 April 2018, 46 Perusahaan Industri Properti peraih penghargaan Property Award 2018 dari Warta Ekonomi. (Rahayu, 2018) Diantara-Nya :

\begin{tabular}{|c|c|l|}
\hline No & Category & Winning Company \\
\hline \multirow{10}{*}{1} & & PT Agung \\
& & Podomoro Land Tbk \\
& & (Podomoro Park \\
& & Bandung), Intiland \\
& & Development Tbk \\
& Top Marketing & (Serenia Hills), PT \\
& Communication in & Bakrieland \\
& Housing Category & Development Tbk \\
& (Komunikasi & (Bogor Nirwana \\
& Pemasaran Top di & Residence), PT \\
& Kategori & Jababeka Tbk \\
& Perumahan) & (D'Java Residence), \\
& & PT Gapura \\
& & Kencana Abadi \\
& & (Pinewood \\
& & Residence), \\
& & Suryamas Group \\
& & (Royal Tajur) \\
& & \\
\hline
\end{tabular}




\begin{tabular}{|c|c|c|}
\hline No & Category & Winning Company \\
\hline 2 & $\begin{array}{c}\text { Top Marketing } \\
\text { Communication in } \\
\text { City \& Township } \\
\text { Category } \\
\text { (Komunikasi } \\
\text { Pemasaran Top di } \\
\text { Kategori Kota \& } \\
\text { Kotapraja) }\end{array}$ & $\begin{array}{l}\text { PT Lippo Karawaci } \\
\text { Tbk (Meikarta), PT } \\
\text { Bumi Serpong } \\
\text { Damai Tbk (Nuvasa } \\
\text { Bay), PT } \\
\text { Summarecon } \\
\text { Agung Tbk } \\
\text { (Summarecon } \\
\text { Serpong), PT } \\
\text { Ciputra } \\
\text { Development Tbk } \\
\text { (Citraland The } \\
\text { Green Lake } \\
\text { Surabaya), PT } \\
\text { Modernland Realty } \\
\text { Tbk (Jakarta } \\
\text { Garden City), PT } \\
\text { Grahabuana } \\
\text { Cikarang (Jababeka } \\
\text { Residence), PT } \\
\text { Cowell } \\
\text { Development Tbk } \\
\text { (Borneo Paradiso), } \\
\text { PT Astra Modern } \\
\text { Land (Astra Modern } \\
\text { Land) }\end{array}$ \\
\hline 3 & $\begin{array}{c}\text { Top Marketing } \\
\text { Communication in } \\
\text { Apartment } \\
\text { Category } \\
\text { (Komunikasi } \\
\text { Pemasaran Top di } \\
\text { Kategori } \\
\text { Apartemen) }\end{array}$ & $\begin{array}{l}\text { PT Agung Sedayu } \\
\text { Group (Menteng } \\
\text { Park), PT Alam } \\
\text { Sutera Realty Tbk } \\
\text { (Kota Ayodhya), PT } \\
\text { Duta Paramindo } \\
\text { Sejahtera (Green } \\
\text { Pramuka City), PT } \\
\text { Jakarta Setiabudi } \\
\text { Internasional Tbk } \\
\text { (Setiabudi Sky } \\
\text { Garden), The } \\
\text { Capitol Group (The } \\
\text { Capitol), PT } \\
\text { Metropolitan Land } \\
\text { Tbk (Kaliana } \\
\text { Apartment), } \\
\text { PatraLand (PT } \\
\text { Patra Jasa), } \\
\text { (Tamansari } \\
\text { Urbano), PT } \\
\text { Perdana Gapura } \\
\text { Prima Tbk (Bellevue } \\
\text { Place Jakarta) }\end{array}$ \\
\hline
\end{tabular}

\begin{tabular}{|c|c|c|}
\hline No & Category & Winning Company \\
\hline 4 & $\begin{array}{c}\text { Top Marketing } \\
\text { Communication in } \\
\text { Mixed-Use } \\
\text { Building Category } \\
\text { ( } \\
\text { Komunikasi } \\
\text { Pemasaran Top } \\
\text { dalam Kategori } \\
\text { Bangunan } \\
\text { Penggunaan } \\
\text { Campuran) }\end{array}$ & $\begin{array}{l}\text { PT Pakuwon Jati } \\
\text { Tbk (Kota } \\
\text { Kasablanka } \\
\text { Superblock), PT } \\
\text { Agung Podomoro } \\
\text { Land Tbk } \\
\text { (Podomoro City), } \\
\text { Trans Property (CT } \\
\text { Corp), (Trans Park } \\
\text { Cibubur), PT } \\
\text { Putragaya Wahana } \\
\text { (Thamrin Nine), PT } \\
\text { Pancakarya } \\
\text { Griyatama } \\
\text { (TangCity } \\
\text { Superblock), PT } \\
\text { Megapolitan } \\
\text { Development Tbk } \\
\text { (Centro Cinere), } \\
\text { Tamara Land } \\
\text { (Tamara Group), } \\
\text { (Kebayoran Icon), } \\
\text { PT Pikko Land } \\
\text { Development Tbk } \\
\text { (Thamrine District } \\
\text { Bekasi) }\end{array}$ \\
\hline 5 & $\begin{array}{c}\text { Top Marketing } \\
\text { Communication in } \\
\text { Office Building } \\
\text { Category } \\
\text { (Komunikasi } \\
\text { Pemasaran Top } \\
\text { dalam Kategori } \\
\text { Gedung Kantor) } \\
\end{array}$ & $\begin{array}{l}\text { PT Bintang Rajawali } \\
\text { Perkasa (L'avenue), } \\
\text { PT Chitaland } \\
\text { Perkasa (Chitaland } \\
\text { Tower), PT } \\
\text { Greenwood } \\
\text { Sejahtera Tbk (TCC } \\
\text { Batavia) }\end{array}$ \\
\hline 6 & $\begin{array}{c}\text { Top Marketing } \\
\text { Communication in } \\
\text { Hotel \& Resort } \\
\text { Category ( } \\
\text { Komunikasi } \\
\text { Pemasaran Top di } \\
\text { Kategori Hotel \& } \\
\text { Resor) }\end{array}$ & $\begin{array}{l}\text { Trans Property (CT } \\
\text { Corp), (Trans } \\
\text { Luxury Hotel), PT } \\
\text { PP Properti Tbk } \\
\text { (Prime Park } \\
\text { Bandung), Springhill } \\
\text { Group (Spring Hill } \\
\text { Villa \& Resort } \\
\text { Jimbaran Hijau) }\end{array}$ \\
\hline 7 & $\begin{array}{l}\text { Top Marketing } \\
\text { Communication in } \\
\text { Trade Center } \\
\text { Category( } \\
\text { Komunikasi } \\
\text { Pemasaran Top } \\
\text { dalam Kategori } \\
\text { Pusat } \\
\text { Perdagangan) }\end{array}$ & $\begin{array}{l}\text { PT Agung Sedayu } \\
\text { Group (PIK } \\
\text { Avenue), PT Bumi } \\
\text { Serpong Damai Tbk } \\
\text { (AEON Mall), PT } \\
\text { Ciputra } \\
\text { Development Tbk } \\
\text { (Lotte Shopping } \\
\text { Avenue), PT Central } \\
\text { Prima Kelola } \\
\text { (Central Park Mall), } \\
\text { PT Nirvana Wastu }\end{array}$ \\
\hline
\end{tabular}




\begin{tabular}{|c|c|c|}
\hline No & Category & Winning Company \\
\hline & & $\begin{array}{l}\text { Pratama (The Park } \\
\text { Solo) }\end{array}$ \\
\hline 8 & $\begin{array}{c}\text { Top Marketing } \\
\text { Communication in } \\
\text { Industrial Estate( } \\
\text { Komunikasi } \\
\text { Pemasaran Top di } \\
\text { Kawasan Industri) }\end{array}$ & $\begin{array}{l}\text { PT Lippo Cikarang } \\
\text { Tbk (Lippo Cikarang } \\
\text { Industrial Estate), } \\
\text { PT Modern } \\
\text { Industrial Estate } \\
\text { (Modern Cikande), } \\
\text { Puradelta Lestari } \\
\text { Tbk (Kawasan } \\
\text { Industri Delta Mas), } \\
\text { PT Bekasi Fajar } \\
\text { Industrial Estate } \\
\text { Tbk (Bekasi Fajar } \\
\text { Indsutrial) }\end{array}$ \\
\hline 9 & $\begin{array}{c}\text { Smart Marketing } \\
\text { Communication } \\
\text { Innovation with } \\
\text { APP Smart } \\
\text { Property Tools ( } \\
\text { Inovasi } \\
\text { Komunikasi } \\
\text { Pemasaran } \\
\text { Cerdas dengan } \\
\text { APP Alat Properti } \\
\text { Cerdas) }\end{array}$ & $\begin{array}{l}\text { PT Adhi Persada } \\
\text { Properti } \\
\text { (Pengembangan } \\
\text { Realti dan Properti) }\end{array}$ \\
\hline
\end{tabular}

Tergelitik rasa penasaran peneliti pada kabar ini, untuk menganalisis kinerja perusahaan-perusahaan induk yang anak-anak perusahaannya meraih penghargaan tersebut, apakah layak berinvestasi saham di perusahaanperusahaan induknya.

Dari 46 Perusahaan yang meraih penghargaan untuk melakukan analisis pada perusahaan di atas, peneliti menggunakan teknik analisis CAPM (Capital Asset Pricing Model) yaitu model dimana kondisi pasar berada dititik keseimbangan, risiko yang tidak sistematis akan rendah sehingga risiko sistematis yang hanya akan mempengaruhi sekuritas prices. asset pricing model akan bisa menjelaskan harga saham ketika keadaan pasar yang sedang equilibrium sebagai model keseimbangan. Model keseimbangan yang banyak diminati oleh investor yaitu metode yang didevelop oleh William $F$. Sharpe, John Lintner dan Jan Mossinini.(Warman, 2018)

Cara ini adalah cara sederhana yang sering dilakukan oleh seorang investor pada pengambilan keputusan transaksi saham di pasar modal. Hematnya model ini digunakan, dikarenakan dalam berinvestasi haruslah efektif dan efisien serta tahu kapan menjual dan kapan membeli, yang pada dasarnya seorang investor dituntut menentukan pengembalian (required return) dari suatu asset, besarnya rate of return seharusnya berbanding lurus dengan risiko yang diambil. Dalam perhitungan CAPM tentunya menggunakan beberapa variabel yang harus dipenuhi diantara-Nya Rf (risk free rate), $\beta$ (beta), dan $\mathrm{Rm}$ (return market). (Saraswati, 2020)

\section{KAJIAN LITERATUR}

Investasi adalah akumulasi suatu aktiva dengan suatu harapan untuk mendapatkan keuntungan pada masa yang akan datang. Investasi disebut juga sebagai penanaman modal. Hal Ini adalah kebalikan dari divestasi pada aktiva yang ada pada masa lampau. (Wikipedia, 2020)

Pasar modal adalah tempat dalam kata lain suatu sarana yang menemukan penjual sekuritas yang membutuhkan kas dan pembeli sekuritas yang kelebihan kas untuk melakukan kegiatan transaksi sekuritas. Hal yang membedakan pasar modal dengan pasar yang lainnya adalah pasar modal memperjualbelikan suatu profit atau suatu keuntungan di masa yang akan datang dari aktiva yang dibeli saat ini. Alat yang jual belikan dalam pasar modal ini antara lain seperti saham 
biasa, saham preferen, right, waran, obligasi, kontrak opsi .(Tandelilin, 2010)

Indeks harga saham adalah suatu indikator yang penting yang digunakan untuk memperlihatkan pergerakan harga saham.(Darmadji \& Tjiptono dan Fachrudin, 2012)

Indeks yang digunakan dalam penelitian ini yang bertujuan untuk mengukur suatu kinerja saham listed di Bursa Efek Indonesia adalah Indeks Harga Saham Gabungan (IHSG). (Hadi, 2013)

Risiko dalam investasi merupakan suatu besarnya penyimpangan antara tingkat pengembalian yang diharapkan dengan tingkat pengembalian yang didapat pada kenyataannya. Risiko yang dimiliki oleh setiap aktiva berisiko yaitu gabungan dari risiko secara sistematis dan risiko yang tidak secara sistematis atau yang biasa disebut sebagai risiko total/ risiko keseluruhan.(Hartono, 2013)

$$
\beta_{i}=\frac{\sigma_{i} M}{\sigma^{2} M}
$$

Nilai beta portofolio pasar adalah 1 $(\beta=1)$.(Jones, 2009)

Bila suatu saham memiliki nilai beta lebih dari $1 \quad(\beta>1)$ memperlihatkan pergerakan saham yang lebih berfluktuasi dari pada pergerakan pasar pada umumnya, sedangkan bila beta saham yang kurang dari $1(\beta<1)$ memperlihatkan pergerakan yang lebih kondusif (tidak berfluktuasi) dibandingkan pergerakan pasar pada semestinya. Saham adalah suatu bukti penyertaan kepemilikan modal pada suatu perusahaan yang tercantum dengan jelas pada nilai nominalnya, nama perusahaan dengan hak dan kewajiban yang jelas kepada setiap pemegangnya.(Fahmi, 2015)

Dalam manajemen investasi, ada 2 Return yakni return yang harapkan (expected return) serta return yang terealisasi (realized return), return yang diharapkan merupakan tingkat return yang diantisipasi investor dimasa datang. Sedangkan return yang terealisasi atau return yang terjadi merupakan tingkat return yang didapat investor pada masa lalu.(Adrianhg, 2018)

Pada waktu investor menginvestasikan kekayaannya, dia akan mensyaratkan tingkat return tertentu dan jika periode investasi telah berlalu investor tersebut akan mengharapkan tingkat return yang sesungguhnya dia terima.

Antara tingkat return yang diharapkan dan tingkat return yang terjadi yang diperoleh investor dari investasi yang dilakukan mungkin saja berbeda. Pebedaan antara return yang diharapkan dengan return yang benar-benar diterima (return yang terjadi) merupakan risiko yang harus selalu dianalisis dalam proses investasi. (Tandelilin, 2010)

\section{Rate of return Saham Individu}

Rate of return dari keseluruhan suatu investasi dalam jangka periode tertentu.

$$
R_{i, t}=\frac{\left(P_{t}-P_{t-1}\right)+D_{t}}{P_{t-1}}
$$

\section{Rate of return Pasar}

Rate of return pasar adalah tingkat pengembalian yang didasarkan pada perkembangan indeks harga saham. Indeks pasar yang bisa dipilih untuk pasar BEI misalnya adalah IHSG atau indeks lain untuk saham-saham yang aktif saja.

$$
R_{m, t}=\frac{I H S G_{t}-I H S G_{t-1}}{I H S G_{t-1}}
$$

\section{Rate of return Bebas Risiko}

Rate of return bebas risiko pengembalian yang diperoleh dari aktiva bebas risiko. Sertifikat Bank Indonesia (SBI) adalah salah satu aktiva bebas risiko. 


$$
R_{f}=\frac{\sum R_{f}}{N}
$$

\section{Rate of return yang Diharapkan (Expected Return)}

Return harapan merupakan pengembalian yang diharapkan akan didapat investor dari suatu investasi pada masa yang akan datang.

$$
E\left(R_{i}\right)=R_{f}+\beta_{i \cdot}\left[E\left(R_{m}\right)-R_{f}\right]
$$

Model CAPM (Capital Asset Pricing Model) bertujuan untuk dapat memahami perilaku investor secara menyeluruh, mekanisme pembentukan harga dan pengembalian pasar dalam bentuk yang lebih sederhana, menentukan risiko yang relevan pada suatu aktiva dan hubungan risk dan return yang diharapkan untuk suatu aktiva ketika pasar dalam kondisi ekuibrium. (Septiana et al., 2018)

Jadi, CAPM bermanfaat untuk seorang investor dalam menganalisa return asset berisiko pada investasi. CAPM memberikan asumsi risiko dan tingkat pengembalian saham mempunyai hubungan positif. Semakin tinggi risiko maka semakin tinggi tingkat imbal hasil saham dan kebalikannya.

Dalam penelitian sebelumnya yang menyatakan bahwa semakin besar risiko yang ditanggung, maka semakin besar pula return yang akan didapatkan dari investasi pada sebuah sekuritas, hal ini beliau dapat dari hasil hitungan jika $\beta_{i}$ semakin besar maka $E\left(R_{i}\right)$ ikut semakin besar pula. (Haidiati \& Azizah, 2016)

Saham yang memiliki tingkat return individu > tingkat return yang diharapkan $\left[R_{i}>E\left(R_{i}\right)\right]$ maka keputusan investasi yang tepat dilakukan investor yaitu membeli saham efisien dan menjualnya kembali ketika harga sahamnya naik.

Sedangkan saham yang menghasilkan return yang tidak memenuhi return-nya yang diharapkan oleh investor $\left[R_{i}<E\left(R_{i}\right)\right]$. Investor disarankan untuk menjual saham tidak efisien tersebut atau melakukan short sell sebelum waktu harga saham menurun.

Hipotesis adalah jawaban sementara yang harus diuji kembali tingkat kebenarannya. Hipotesis yang dibuat, seperti berikut :

$H_{0}$ : Semua Perusahaan Peraih Penghargaan Property Award 2018 layak untuk dibeli sahamnya.

$H_{a}$ : Tidak Semua Perusahaan Peraih Penghargaan Property Award 2018 layak untuk dibeli sahamnya.

\section{METODE PENELITIAN}

Metode penelitian yang digunakan dalam penelitian ini adalah penelitian deskriptif dengan menggunakan data kuantitatif yaitu penelitian tentang analisis data dengan cara mendeskripsikan atau menggambarkan suatu informasi dari data yang telah terkumpul sebagaimana adanya tanpa bermaksud membuat kesimpulan yang berlaku untuk digeneralisasi. (Ali Muhson, 2006)

Data didapat dari Yahoo Finance. Populasi penelitian dilakukan kepada perusahaan-perusahaan induk yang anak perusahaannya meraih penghargaan Property Award 2018 dari Warta Ekonomi sebanyak 46 perusahaan. Teknik pengambilan sampel menggunakan teknik pengambilan sampel bertujuan atau disebut dengan purposive sampling adalah pengambilan sampel secara sengaja sesuai dengan persyaratan sampel yang diperlukan. (Statistik, 2014) dimana dengan beberapa kriteria, kriteria diantara-Nya adalah :

1. Ada perusahaan induknya dan terdaftar di Bursa Efek Indonesia

2. Mempunyai data harga penutupan yang telah disesuaikan (adj Close) secara konsisten

3. Perusahaan peraih penghargaan yang mempunyai induk perusahaan 
sama, hanya diambil cuman satu data perusahaan indukya

4. Memiliki data dari 1 Januari 2015 s/d 1 Desember 2019

Sehingga dalam penentuan sample dalam penelitian ini peneliti mengidentifikasi hanya ada 23 perusahaan yang didapat. Data sebagai berikut :

Tabel 1. Perusahaan Induk

\begin{tabular}{clc}
\hline No & \multicolumn{1}{c}{ Perusahaan } & Kode \\
\hline $\mathbf{1}$ & PT Agung Podomoro Land Tbk & APLN \\
\hline $\mathbf{2}$ & Intiland Development Tbk & DILD \\
\hline $\mathbf{3}$ & PT Bakrieland Development Tbk & ELTY \\
\hline $\mathbf{4}$ & PT Jababeka Tbk & KIJA \\
\hline $\mathbf{5}$ & Suryamas Group & SMDM \\
\hline $\mathbf{6}$ & PT Lippo Karawaci Tbk & LPKR \\
\hline $\mathbf{7}$ & PT Bumi Serpong Damai Tbk & BSDE \\
\hline $\mathbf{8}$ & PT Summarecon Agung Tbk & SMRA \\
\hline $\mathbf{9}$ & PT Ciputra Development Tbk & CTRA \\
\hline $\mathbf{1 0}$ & PT Modernland Realty Tbk & MDLN \\
\hline $\mathbf{1 1}$ & PT Cowell Development Tbk & COWL \\
\hline $\mathbf{1 2}$ & PT Alam Sutera Realty Tbk & ASRI \\
\hline $\mathbf{1 3}$ & PT Jakarta Setiabudi Internasional Tbk & JSPT \\
\hline $\mathbf{1 4}$ & PT Metropolitan Land Tbk & MTLA \\
\hline $\mathbf{1 5}$ & PT Perdana Gapura Prima Tbk & GPRA \\
\hline $\mathbf{1 6}$ & PT Pakuwon Jati Tbk & PWON \\
\hline $\mathbf{1 7}$ & PT Megapolitan Development Tbk & EMDE \\
\hline $\mathbf{1 8}$ & PT Pikko Land Development Tbk & RODA \\
\hline $\mathbf{1 9}$ & PT Greenwood Sejahtera Tbk & GWSA \\
\hline $\mathbf{2 0}$ & PT PP Properti Tbk & PPRO \\
\hline $\mathbf{2 1}$ & PT Lippo Cikarang Tbk & LPCK \\
\hline $\mathbf{2 2}$ & Puradelta Lestari Tbk & DMAS \\
\hline $\mathbf{2 3}$ & PT Bekasi Fajar Industrial Estate Tbk & BEST \\
\hline $\mathbf{S}$ &
\end{tabular}

Sumber: Data Diolah, 2019

Sumber data sekunder adalah sumber yang memberikan data secara tidak langsung kepada peneliti, namun melalui pihak ke tiga yang melakukan proses dokumentasi. (Sugiyono, 2012) Tahapan-tahapan analisis data dalam penelitian ini supaya memberikan hasil informasi yang diharapkan adalah sebagai berikut:

1. Analisis hasil rate of return saham individu $\left(R_{i}\right)$

2. Analisis hasil rate of return pasar $\left(R_{m}\right)$

3. Analisis hasil rate of return bebas risiko $\left(R_{f}\right)$

4. Analisis hasil risiko sistematis atau beta saham individu $\left(\beta_{i}\right)$

5. Analisis hasil rate of return yang diharapkan $\left[E\left(R_{i}\right)\right]$
6. Menggambar Security Market Line (SML)

7. Menggolongkan efisiensi saham dan keputusan investasi saham

\section{HASIL DAN PEMBAHASAN}

\section{Analisis Hasil Rate Of Return} Saham Individu $\left(R_{i}\right)$

Tabel 2 terdapat 17 saham yang memiliki return saham individu negatif $\left(R_{i}<0\right)$ dan 6 saham lainnya memiliki return saham individu positif $\left(R_{i}>0\right)$. Saham dengan nilai $R_{i}$ terendah adalah saham PT Cowell Development Tbk, yaitu sebesar 0,401726649 atau $-40,17 \%$, sedangkan saham dengan $R_{i}$ tertinggi adalah PT Megapolitan Development Tbk, yaitu sebesar 0,139929221 atau $13,99 \%$.

Tabel 2. Rate Of Return Saham Individu $\left(R_{i}\right)$ 1 Januari 2015 s/d 1 Desember 2019

\begin{tabular}{|c|c|c|}
\hline No & Perusahaan & $R_{i}$ \\
\hline 1 & PT Agung Podomoro Land Tbk & $-0,166728644$ \\
\hline 2 & Intiland Development Tbk & $-0,135388268$ \\
\hline 3 & PT Bakrieland Development Tbk & $-0,373948343$ \\
\hline 4 & PT Jababeka Tbk & $-0,000647158$ \\
\hline 5 & Suryamas Group & $-0,003124245$ \\
\hline 6 & PT Lippo Karawaci Tbk & $-0,230085417$ \\
\hline 7 & PT Bumi Serpong Damai Tbk & $-0,089812219$ \\
\hline 8 & PT Summarecon Agung Tbk & $-0,088077587$ \\
\hline 9 & PT Ciputra Development Tbk & $-0,050057967$ \\
\hline 10 & PT Modernland Realty Tbk & $-0,151597003$ \\
\hline 11 & PT Cowell Development Tbk & $-0,401726649$ \\
\hline 12 & PT Alam Sutera Realty Tbk & $-0,164344847$ \\
\hline 13 & PT Jakarta Setiabudi Internasional Tbk & 0,098036811 \\
\hline 14 & PT Metropolitan Land Tbk & 0,030626683 \\
\hline 15 & PT Perdana Gapura Prima Tbk & $-0,223184046$ \\
\hline 16 & PT Pakuwon Jati Tbk & 0,037183418 \\
\hline 17 & PT Megapolitan Development Tbk & 0,139929221 \\
\hline 18 & PT Pikko Land Development Tbk & $-0,364081946$ \\
\hline 19 & PT Greenwood Sejahtera Tbk & $-0,030686828$ \\
\hline 20 & PT PP Properti Tbk & 0,113963515 \\
\hline 21 & PT Lippo Cikarang Tbk & $-0,385200338$ \\
\hline 22 & Puradelta Lestari Tbk & 0,07271157 \\
\hline \multirow[t]{3}{*}{23} & PT Bekasi Fajar Industrial Estate Tbk & $-0,208770639$ \\
\hline & $R_{i}$ Tertinggi & 0,139929221 \\
\hline & $R_{i}$ Terendah & $-0,401726649$ \\
\hline
\end{tabular}

Sumber: Data Diolah, 2019

2. Analisis Hasil Rate Of Return Pasar $\left(R_{m}\right)$

Rate of return didapat pada adj close IHSG per bulan dibagi dengan adj 
close IHSG pada bulan sebelumnya lalu di Geometrikan dan di annualkan dengan persamaan $\left(1+\overline{X_{\text {geom }}}\right)^{12}-$ 1 , sehingga dihasilkan nilai untuk $\boldsymbol{R}_{\boldsymbol{m}}$ sebesar 0,03077958955, atau $3,078 \%$.

Tabel 3. Rate Of Return Pasar $\left(\boldsymbol{R}_{m}\right)$

1 Januari 2015 s/d 1 Desember 2019

\section{Month Market}

Return

Geometric

0,002529477

Average

Annual

Market Return

$3,0780 \%$

$\left(\boldsymbol{R}_{m}\right)$

Sumber: Data Diolah, 2019

3. Analisis Hasil Rate Of Return Bebas Risiko $\left(R_{f}\right)$

Aktiva bebas risiko yang dipakai dalam perhitungan $\boldsymbol{R}_{\boldsymbol{f}}$ adalah suku bunga $\mathrm{SBI}$ atau $\mathrm{BI}$ Rate periode Januari 2015 - Desember 2019. Hasil analisis memperlihatkan rata-rata/ tahun bahwa tingkat pengembalian bebas risiko di Indonesia sebesar 0,062 atau $6,2 \%$, sedangkan rata-rata per bulan sebesar 0,0052083 atau $0,521 \%$. Perhitungan $\boldsymbol{R}_{\boldsymbol{f}}$ adalah sebagai berikut :

$$
R_{f}=\frac{0,062}{12}=0,0052083
$$

\section{Analisis Hasil Risiko Sistematis} Atau Beta Saham individu $\left(\boldsymbol{\beta}_{i}\right)$

Tabel dibawah ini memperlihatkan hasil beta saham yang berbeda-beda. Sebanyak 12 saham dari 23 saham perusahaan memiliki $\boldsymbol{\beta}_{\boldsymbol{i}}$ lebih dari 1 $\left(\boldsymbol{\beta}_{\boldsymbol{i}}>1\right)$ dan 11 saham lainnya memiliki $\beta i$ dengan nilai di bawah $1\left(\boldsymbol{\beta}_{\boldsymbol{i}}<1\right)$. Hal ini memberi penjelasan bahwa dari 12 saham perusahaan dengan beta $>1$, maka saham ini memiliki risiko sistematis yang lebih besar dari risiko pasar dan 11 saham perusahaan dengan beta $<1$, maka saham ini memiliki risiko sistematis yang lebih kecil dari risiko pasar.

Saham PT Bekasi Fajar Industrial Estate Tbk merupakan saham yang dikategorikan paling agresif karena memiliki nilai beta saham paling tinggi, yaitu sebesar 2,243512725. Saham PT Bakrieland Development Tbk merupakan saham yang dikategorikan paling defensif karena memiliki nilai beta paling rendah sebesar $-13,55388858$.

Tabel 4. Beta Saham Individu $\left(\beta_{i}\right)$

1 Januari 2015 s/d 1 Desember 2019

\begin{tabular}{|c|c|c|}
\hline No & Perusahaan & $\boldsymbol{\beta}_{\boldsymbol{i}}$ \\
\hline 1 & PT Agung Podomoro Land Tbk & 1,287542325 \\
\hline 2 & Intiland Development Tbk & $-0,103549801$ \\
\hline 3 & PT Bakrieland Development Tbk & $-13,55388858$ \\
\hline 4 & PT Jababeka Tbk & 1,555555431 \\
\hline 5 & Suryamas Group & 0,236023518 \\
\hline 6 & PT Lippo Karawaci Tbk & 0,97984321 \\
\hline 7 & PT Bumi Serpong Damai Tbk & 1,597205877 \\
\hline 8 & PT Summarecon Agung Tbk & 2,192959421 \\
\hline 9 & PT Ciputra Development Tbk & 1,763508561 \\
\hline 10 & PT Modernland Realty Tbk & 0,531526834 \\
\hline 11 & PT Cowell Development Tbk & 1,439961985 \\
\hline 12 & PT Alam Sutera Realty Tbk & 1,570312573 \\
\hline 13 & PT Jakarta Setiabudi Internasional Tbk & 0,464595624 \\
\hline 14 & PT Metropolitan Land Tbk & 0,811859312 \\
\hline 15 & PT Perdana Gapura Prima Tbk & 0,230239817 \\
\hline 16 & PT Pakuwon Jati Tbk & 1,513147619 \\
\hline 17 & PT Megapolitan Development Tbk & $-0,021980042$ \\
\hline 18 & PT Pikko Land Development Tbk & $-0,642659559$ \\
\hline 19 & PT Greenwood Sejahtera Tbk & 0,726187252 \\
\hline 20 & PT PP Properti Tbk & 1,93258694 \\
\hline 21 & PT Lippo Cikarang Tbk & 1,682305842 \\
\hline 22 & Puradelta Lestari Tbk & 1,131286229 \\
\hline \multirow[t]{3}{*}{23} & PT Bekasi Fajar Industrial Estate Tbk & 2,243512725 \\
\hline & $\beta_{i}$ Tertinggi & 2,243512725 \\
\hline & $\beta_{i}$ Terendah & $-13,55388858$ \\
\hline
\end{tabular}

Sumber: Data Diolah, 2019

\section{Analisis hasil rate of return yang} diharapkan $\left[\boldsymbol{E}\left(\boldsymbol{R}_{\boldsymbol{i}}\right)\right]$

Tabel 5 menyajikan perhitungan $E\left(R_{i}\right)$ berdasarkan metode CAPM dari 23 perusahaan yang terpilih sebagai sampel penelitian. Nilai $E\left(R_{i}\right)$ paling rendah dimiliki oleh saham PT Bekasi Fajar Industrial Estate Tbk dengan angka 0,008665144 atau $-0,87 \%$. Sedangkan perusahaan PT Bakrieland Development Tbk memiliki 
nilai $E\left(R_{i}\right)$ paling tinggi di antara 22 saham lainnya, yaitu sebesar 0,492434909 atau $49,24 \%$. Saham perusahaan dengan nilai $E\left(R_{i}\right)$ tertinggi dan terendah tidak sama dengan saham perusahaan dengan nilai $\beta_{i}$ tertinggi dan terendah. Hal ini membuktikan suatu penyanggahan pada pernyataan empiris dari penelitian sebelumnya yang dilakukan Din Haidiati Topowijono Devi Farah Azizah yang menyatakan bahwa semakin besar risiko yang ditanggung, maka semakin besar pula return yang akan didapatkan dari investasi pada sebuah sekuritas. Ternyata dalam penelitian ini hasilnya terbalik karena semakin tinggi $\beta_{i}$ akan memungkinkan $E\left(R_{i}\right)$ harapan akan pengembalian yang didapat semakin rendah.

Tabel 5. Rate Of Return Yang Diharapkan $\left[E\left(R_{i}\right)\right]$ 1 Januari 2015 s/d 1 Desember 2019

\begin{tabular}{|c|c|c|}
\hline No & Perusahaan & $E\left(\boldsymbol{R}_{\boldsymbol{i}}\right)$ \\
\hline 1 & PT Agung Podomoro Land Tbk & 0,021658629 \\
\hline 2 & Intiland Development Tbk & 0,065784642 \\
\hline 3 & PT Bakrieland Development Tbk & 0,492434909 \\
\hline 4 & PT Jababeka Tbk & 0,013157143 \\
\hline 5 & Suryamas Group & 0,055013237 \\
\hline 6 & PT Lippo Karawaci Tbk & 0,031418971 \\
\hline 7 & PT Bumi Serpong Damai Tbk & 0,011835974 \\
\hline 8 & PT Summarecon Agung Tbk & $-0,007061573$ \\
\hline 9 & PT Ciputra Development Tbk & 0,006560785 \\
\hline 10 & PT Modernland Realty Tbk & 0,045639751 \\
\hline 11 & PT Cowell Development Tbk & 0,016823815 \\
\hline 12 & PT Alam Sutera Realty Tbk & 0,012689041 \\
\hline 13 & PT Jakarta Setiabudi Internasional Tbk & 0,047762836 \\
\hline 14 & PT Metropolitan Land Tbk & 0,036747489 \\
\hline 15 & PT Perdana Gapura Prima Tbk & 0,055196699 \\
\hline 16 & PT Pakuwon Jati Tbk & 0,014502336 \\
\hline 17 & PT Megapolitan Development Tbk & 0,063197216 \\
\hline 18 & PT Pikko Land Development Tbk & 0,082885425 \\
\hline 19 & PT Greenwood Sejahtera Tbk & 0,039465042 \\
\hline 20 & PT PP Properti Tbk & 0,001197549 \\
\hline 21 & PT Lippo Cikarang Tbk & 0,009136568 \\
\hline 22 & Puradelta Lestari Tbk & 0,026615136 \\
\hline \multirow[t]{3}{*}{23} & PT Bekasi Fajar Industrial Estate Tbk & $-0,008665144$ \\
\hline & $E\left(R_{i}\right)$ Tertinggi & 0,492434909 \\
\hline & $E\left(R_{i}\right)$ Terendah & $-0,008665144$ \\
\hline
\end{tabular}

Sumber: Data Diolah, 2019

\section{Menggambar Security Market Line (SML)}

Security Market Line dibentuk dengan beta $\left(\beta_{i}\right)$ dan $E\left(R_{i}\right)$ dengan cara menghubungkan titik-titik beta $\left(\beta_{i}\right)$ dan $E\left(R_{i}\right)$ yang berutan dari beta. Garis Pasar Sekuritas ini memiliki slope yang $(+)$ positif karena semakin rendah nilai beta $\left(\beta_{i}\right)$, semakin besar pula nilai tingkat imbal hasil yang diharapkan $E\left(R_{i}\right)$. Gambaran terlihat dari pergerakan garis yang menjulang ke atas.

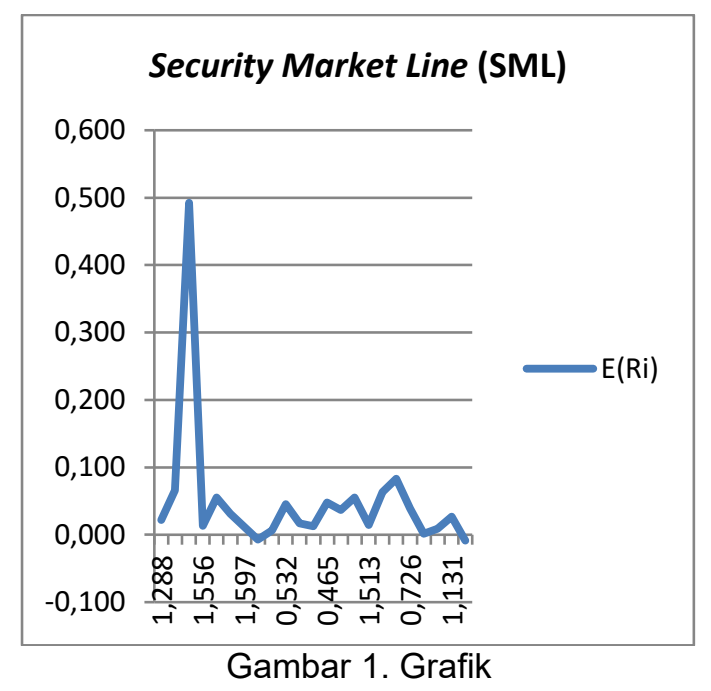

Sumber: Data Diolah, 2019

\section{Penggolongan Efisiensi Saham dan Keputusan Investasi Saham}

Tabel 6. Evaluasi Saham dan Keputusan Investasi 1 Januari 2015 s/d 1 Desember 2019

\begin{tabular}{cccccc}
\hline No & Kode & $\boldsymbol{R}_{\boldsymbol{i}}$ & $\boldsymbol{E}\left(\boldsymbol{R}_{\boldsymbol{i}}\right)$ & $\mathbf{E V}$ & $\mathbf{K P}$ \\
\hline $\mathbf{1}$ & APLN & $-0,166728644$ & 0,021658629 & TE & $\mathrm{J}$ \\
\hline $\mathbf{2}$ & DILD & $-0,135388268$ & 0,065784642 & TE & $\mathrm{J}$ \\
\hline $\mathbf{3}$ & ELTY & $-0,373948343$ & 0,492434909 & TE & $\mathrm{J}$ \\
\hline $\mathbf{4}$ & KIJA & $-0,000647158$ & 0,013157143 & TE & $\mathrm{J}$ \\
\hline $\mathbf{5}$ & SMDM & $-0,003124245$ & 0,055013237 & TE & $\mathrm{J}$ \\
\hline $\mathbf{6}$ & LPKR & $-0,230085417$ & 0,031418971 & TE & $\mathrm{J}$ \\
\hline $\mathbf{7}$ & BSDE & $-0,089812219$ & 0,011835974 & TE & $\mathrm{J}$ \\
\hline $\mathbf{8}$ & SMRA & $-0,088077587$ & $-0,007061573$ & TE & $\mathrm{J}$ \\
\hline $\mathbf{9}$ & CTRA & $-0,050057967$ & 0,006560785 & TE & $\mathrm{J}$ \\
\hline $\mathbf{1 0}$ & MDLN & $-0,151597003$ & 0,045639751 & TE & $\mathrm{J}$ \\
\hline $\mathbf{1 1}$ & COWL & $-0,401726649$ & 0,016823815 & TE & $\mathrm{J}$ \\
\hline $\mathbf{1 2}$ & ASRI & $-0,164344847$ & 0,012689041 & TE & $\mathrm{J}$ \\
\hline $\mathbf{1 3}$ & JSPT & 0,098036811 & 0,047762836 & $\mathrm{E}$ & $\mathrm{B}$ \\
\hline $\mathbf{1 4}$ & MTLA & 0,030626683 & 0,036747489 & TE & $\mathrm{J}$ \\
\hline $\mathbf{1 5}$ & GPRA & $-0,223184046$ & 0,055196699 & TE & $\mathrm{J}$ \\
\hline $\mathbf{1 6}$ & PWON & 0,037183418 & 0,014502336 & $\mathrm{E}$ & $\mathrm{B}$ \\
\hline $\mathbf{1 7}$ & EMDE & 0,139929221 & 0,063197216 & $\mathrm{E}$ & $\mathrm{B}$ \\
\hline $\mathbf{1 8}$ & RODA & $-0,364081946$ & 0,082885425 & TE & $\mathrm{J}$ \\
\hline $\mathbf{1 9}$ & GWSA & $-0,030686828$ & 0,039465042 & TE & $\mathrm{J}$ \\
\hline $\mathbf{2 0}$ & PPRO & 0,113963515 & 0,001197549 & $\mathrm{E}$ & $\mathrm{B}$ \\
\hline
\end{tabular}




\begin{tabular}{|c|c|c|c|c|c|}
\hline No & Kode & $\boldsymbol{R}_{i}$ & $E\left(\boldsymbol{R}_{i}\right)$ & EV & KP \\
\hline 21 & LPCK & $-0,385200338$ & 0,009136568 & $\mathrm{TE}$ & $\mathrm{J}$ \\
\hline 22 & DMAS & 0,07271157 & 0,026615136 & $E$ & B \\
\hline 23 & BEST & $-0,208770639$ & $-0,008665144$ & TE & $\mathrm{J}$ \\
\hline \multicolumn{6}{|c|}{ Sumber: Data Diolah, 2019} \\
\hline & & $\begin{array}{l}\text { idak Efisien } \\
\text { eli }\end{array}$ & $\begin{array}{l}\text { Menjual } \\
\text { Efisien }\end{array}$ & & \\
\hline
\end{tabular}

Hasil analisis memperlihatkan bahwa dari 23 saham yang terpilih sebagai sampel dari penelitian ini, terdapat 5 saham efisien dan 18 saham tidak efisien berdasarkan metode CAPM. Saham-saham efisien adalah saham undervalued dengan nilai $R_{i}>$ nilai $E\left(R_{i}\right)$. Saham-saham efisien yaitu PPRO, EMDE, JSPT, DMAS dan PWON. Sedangkan saham yang tidak efisien adalah saham yang memiliki nilai $R_{i}<$ nilai $E\left(R_{i}\right)$ dan dikatakan saham overvalued. Saham-saham tidak efisien tersebut yaitu APLN, DILD, ELTY, KIJA, SMDM, LPKR, BSDE, SMRA, CTRA, MDLN, COWL, ASRI, MTLA, GPRA, RODA, GWSA, LPCK dan BEST.

Hasil perhitungan CAPM sahamsaham yang bisa dijadikan pilihan oleh investor dalam berinvestasi. Dimana semakin besar selisih nilai $R_{i}$ dengan nilai $E\left(R_{i}\right)$ menyatakan bahwa semakin menguntungkan saham efisien tersebut. Maka urutan rank saham efisien yang didasari atas selisih $R_{i}$ dan $E\left(R_{i}\right)$ terlihat pada tabel dibawah ini.

Tabel 7. Urutan Rekomendasi Saham

1 Januari 2015 s/d 1 Desember 2019

\begin{tabular}{|c|c|c|c|c|c|}
\hline $\begin{array}{l}\mathrm{N} \\
\mathrm{O}\end{array}$ & Perusahaan & Kode & $\boldsymbol{R}_{\boldsymbol{i}}$ & $\boldsymbol{E}\left(\boldsymbol{R}_{\boldsymbol{i}}\right)$ & $\begin{array}{c}\boldsymbol{R}_{\boldsymbol{i}}- \\
\left.E\left(\boldsymbol{R}_{\boldsymbol{i}}\right)\right)\end{array}$ \\
\hline \multirow{2}{*}{1} & \multirow{2}{*}{ PT PP Properti Tbk } & PP & 0,1139 & 0,0011 & 0,1127 \\
\hline & & RO & 63515 & 97549 & 65966 \\
\hline \multirow{2}{*}{2} & PT Megapolitan & EM & 0,1399 & 0,0631 & 0,0767 \\
\hline & Development Tbk & $\mathrm{DE}$ & 29221 & 97216 & 32005 \\
\hline \multirow{2}{*}{3} & PT Jakarta Setiabudi & JS & 0,0980 & 0,0477 & 0,0502 \\
\hline & Internasional Tbk & PT & 36811 & 62836 & 73975 \\
\hline \multirow{2}{*}{4} & \multirow{2}{*}{ Puradelta Lestari Tbk } & DM & 0,0727 & 0,0266 & 0,0460 \\
\hline & & AS & 1157 & 15136 & 96434 \\
\hline \multirow{2}{*}{5} & \multirow{2}{*}{ PT Pakuwon Jati Tbk } & PW & 0,0371 & 0,0145 & 0,0226 \\
\hline & & ON & 83418 & 02336 & 81081 \\
\hline
\end{tabular}

Sumber: Data Diolah, 2019

Sehingga dalam pengambilan hipotesa yaitu $h_{a}$ diterima dan menolak $h_{o}$ yang artinya perusahaan-perusahan Peraih Penghargaan Property Award 2018 tidak semuanya perusahaan layak untuk dibeli sahamnya hanya sebagian saja yang bisa diinvestasikan.

\section{PENUTUP}

Berdasarkan hasil analisis data selama 60 bulan dari Januari 2015 s/d Desember 2019, kesimpulan yang dapat diambil adalah sebagai berikut : Membuktikan suatu penyanggahan pada pernyataan empiris dari penelitian sebelumnya yang dilakukan Din Haidiati Topowijono Devi Farah Azizah yang menyatakan bahwa semakin besar risiko yang ditanggung, maka semakin besar pula return yang akan didapatkan dari investasi pada sebuah sekuritas sektor perbankan. Ternyata dalam penelitian ini yang objeknya sektor properti dan real Estate hasilnya terbalik, dimana semakin tinggi $\beta_{i}$ akan memungkinkan $E\left(R_{i}\right)$ harapan akan pengembalian yang didapat semakin rendah hal ini terlihat di tabel 4 dan tabel 5.

\section{SARAN}

Dari 23 perusahaan yang meraih Propety Award Tahun 2018 menurut warta ekonomi hanya ada 5 perusahaan yang layak dibeli sahamnya untuk saat ini diantara-Nya: PT PP Properti Tbk, PT Megapolitan Development Tbk, PT Jakarta Setiabudi Internasional Tbk, Puradelta Lestari Tbk dan PT Pakuwon Jati Tbk.

\section{DAFTAR PUSTAKA}

Darmadji, \& Tjiptono dan Fachrudin. (2012). Pasar Modal Di Indonesia. Salemba Empat.

Fahmi, I. (2015). Manajemen Investasi (2nd ed.). Salemba Empat.

Hadi, N. (2013). Pasar Modal. Graha Ilmu. 
Hartono, J. (2013). Teori Portofolio dan Analisis Investasi (8th ed.). BPFE.

Jones, C. P. (2009). Investments Analysis and Management (An Indonesian Adaptation). Salemba Empat.

Sugiyono. (2012). Metode Penelitian Kuantitatif, Kualitatif dan R \& D.Bandung:Alfabeta. Metode Penelitian Kuantitatif, Kualitatif Dan R $\mathcal{E} \quad$ D.Bandung:Alfabeta. https://doi.org/10.1017/CBO97811 07415324.004

Tandelilin, E. (2010). Portofolio dan Investasi. In Kanisius.

Haidiati, D., \& Azizah, D. (2016). Penerapanimetodeicapitaliassetipric ingimodeli(Capm) Sebagai Dasar Pengambilan Keputusan Investasi Saham (Studi pada Perusahaan yang Terdaftar di Indeks IDX30 Periode Juli 2012-Juni 2015). Jurnal Administrasi Bisnis S1 Universitas Brawijaya.

Septiana, S., Hariyanto, D., \& Safitri, H. (2018). Analisis Capital Asset Pricing Model Dalam Pengambilan Keputusan Investasi Saham Studi Kasus: Perusahaan Yang Tergabung Di Indeks IDX30. Jurnal Produktivitas. https://doi.org/10.29406/jpr.v5i1.1 260

Adrianhg. (2018). Dalam konteks manajemen investasi perlu dibedakan antara return yang diharapkan. Course Hero.

https://www.coursehero.com/file/ p2qi1p02/Dalam-konteksmanajemen-investasi-perludibedakan-antara-return-yangdiharapkan/

Ali Muhson. (2006). Teknik Analisis Kuantitatif. Makalah Teknik Analisis II. Rahayu, R. (2018). 46 Perusahaan Properti
Peraih Property Award 2018. Warta Ekonomi.

https://www.wartaekonomi.co.id/r ead176428/46-perusahaan-propertiperaih-property-award-2018.html

Saraswati, M. A. B. and R. (2020). Sekilas Tentang CAPM dan Cara Perhitungannya - Rumah Saraswati. Rumah Saraswati. https://rumahsaraswati.co/capmdan-cara-perhitungannya/

Statistik, P. (2014). Teknik pengambilan sampel dengan metode purposive sampling - Portal Statistik. Portal Statistik. http://www.portalstatistik.com/2014/02/teknikpengambilan-sampel-denganmetode.html

Warman, N. (2018). Model Keseimbangan atau Capital Asset Pricing Model I. Pintar Saham. https:/ / pintarsaham.id/modelkeseimbangan-atau-capital-assetpricing-model/

Wikipedia. (2020). Investasi - Wikipedia bahasa Indonesia, ensiklopedia bebas. Wikipedia Indonesias. https://id.wikipedia.org/wiki/Inve stasi 